\title{
Impact of Climate Change on Livestock- A Review
}

\author{
Ramandeep Kaur ${ }^{1}$, Parteek Singh Dhaliwal ${ }^{2}$ and S.S. Dhindsa ${ }^{3}$ \\ ${ }^{1}$ School of Animal Biotechnology, ${ }^{2}$ Veterinary and Animal Husbandry Extension Education \\ ${ }^{3}$ Department of Veterinary Gynaecology and Obstetrics, Guru Angad Dev Veterinary and \\ Animal Sciences University, Ludhiana, India-141004 \\ *Corresponding author
}

\section{A B S T R A C T}

\section{Keywords}

Animal, Climate change, Livestock, Production, Reproduction

Article Info

Accepted:

15 April 2019

Available Online:

10 May 2019
The main occupation in India is agriculture and livestock sector is an integral part of agriculture with a share of 25.6 per cent in its GDP. For sustained production of livestock products, animals must reproduce and produce efficiently. However, there are numerous factors that negatively affect the efficiency of animals. At present, climate change is considered as major factor affecting performance of dairy animals. Exposure of animals to excessive environmental stress causes a marked depression in milk production and reproduction and ultimately lowers the income of dairy farmers. An annual loss of approximately 2 per cent occurs due to heat stress in India. Moreover, the incidence of anestrus and silent ovulation is increased with drastic decrease in pregnancy and calving rates in summer season. Therefore, the current review paper is focused on the impacts of climate change on livestock production, food security, sector's contribution of livestock to climate change and adaptation cum mitigation strategies.

\section{Introduction}

India is predominantly an agricultural country with around 70 per cent of the population involved in agriculture and rearing of livestock. Agriculture sector contributes nearly 15.1 per cent of gross domestic production (GDP) in India.

Livestock sector as a component of agriculture sector contributes 25.6 per cent in agricultural GDP and 4.11 per cent in total GDP, further dairy farming alone contributes 18.0 per cent in agricultural GDP in India.
Indian livestock sector provides sustainability and stability to the national economy by contributing to farm energy and food security. Livestock sector not only

provides essential protein and nutrition to human diet through milk, eggs, meat and byproducts such as hides and skin, blood, bone, fat etc., but also plays an important role in utilization of non-edible agricultural by-products. India possesses second largest number of cattle next to Brazil (13\% of world population), largest number of buffaloes (56\% of world population) in the world. 
To enhance the productivity of dairy animal, it is necessary to develop an understanding of factors affecting its milk production. There are many genetic and non-genetic factors which influence the phenotypic expression of performance traits of livestock. The nongenetic factors such as management, quantity and quality of feed, season, period of calving, age at first calving, parity, etc. influence the milk production of the animal. But, sustainability in livestock production system is largely affected by climate change. Climate change, defined as the long-term imbalance of customary weather conditions such as temperature, radiation, wind and rainfall characteristics of a particular region, is likely to be one of the main challenges for mankind during the present century. Exposure of animals to the hot conditions evokes a series of changes in the biological functions that include depression in feed intake, efficiency and utilization, disturbances in metabolism of water, protein, energy and mineral balances, enzymatic reactions, hormonal secretions and blood metabolites. Such changes result in impairment of reproduction and production performances. Intergovernmental Panel on Climate Change (IPCC) in its Fourth Assessment Report (IPCC, 2007) indicated that many of the developing countries tend to be especially vulnerable to extreme climatic events as they largely depend on climate sensitive sectors like agriculture and forestry. It is likely to aggravate the heat stress in dairy animals and shortage of feed and fodder that would adversely affect their productive and reproductive performance.

Furthermore, the livestock sector is a large source of methane emissions, an important greenhouse gas. Global climate change is primarily caused by greenhouse gas (GHG) emissions that result in warming of the atmosphere (IPCC, 2013). The three main GHGs are carbon dioxide $\left(\mathrm{CO}_{2}\right)$, methane $\left(\mathrm{CH}_{4}\right)$, and nitrous oxide $\left(\mathrm{N}_{2} \mathrm{O}\right)$ (Steinfeld et al., 2006). Although most attention has focused on $\mathrm{CO}_{2}$ butCH $\mathrm{H}_{4}$ toois a potent GHG and both have immense global warming potentials (GWPs). The livestock sector contributes 14.5 per cent of global GHG emissions, and thus may increase land degradation, air and water pollution, and decline biodiversity (Reynolds et al., 2010, Thornton and Gerber, 2010 and Bellarby et al., 2013). Increasing concentrations of GHGs in the atmosphere have contributed to an increase in the earth's atmospheric temperature, an occurrence known as global warming (FAO, 2006).

Climate change, particularly global warming, may strongly affect production performance of farm animals worldwide. Among the environmental variables affecting animals, heat stress seems to be one of the intriguing factors making animal production challenging in many geographical locations in the world (Koubkova et al., 2002). Animal stress level due to temperature rise has been worked out using Temperature Humidity Index (THI) in India (Upadhyay et al., 2008). Livestock Weather Safety Index (LWSI) was developed to classify the combined intensity of temperature and humidity into four categories of THI values: THI less than or equal to 74 is Normal, THI 75-78 is Alert, THI 79-83 is Danger and THI value 84 and above is Emergency condition (Eigenberg et al., 2007). All animals have a range of ambient environmental temperatures termed the thermoneutral zone and temperature below or above this thermoneutral range of the animal create stress conditions in animals. Climate change scenario constructed for India revealed that temperature rise of about or more than $4^{\circ} \mathrm{C}$ is likely to increase uncomfortable days (THI>80) from existing 40 days (10.9\%) to 104 days $(28.5 \%)$ and that would have a negative impact on the livestock production both directly and indirectly. Dhakal et al., (2013) observed climate change 
had negative impact on milk production and lactation length and infertility in Nepal. St. Pierre et al., (2003) estimated a total economic animal loss incurred by the US farm animals due to heat stress to be between 1.69 to 2.36 billion US dollars about 58 per cent of which occurred in the dairy industry.

\section{Impact on milk production}

One of the direct impacts of climate change on livestock is on the milk yield due to neuroendocrine response to climate change. Increase in number and frequency of stressful days (THI more than 80) will impact yield and production of cattle and buffalo (Upadhyay et al., 2007). High-producing dairy cows generate more metabolic heat, thus become more vulnerable to heat stress than low-producing ones. Consequently, when metabolic heat production increases in conjunction with heat stress, milk production declines rapidly (Kadzere et al., 2002 and Berman, 2005).

At all India level an estimated annual loss due to direct thermal stress on livestock is about 1.8 million tonnes of milk (Rs. 2661.62 crores), that is, nearly 2 per cent of the total milk production in the country. Ravagnolo and Misztal (2000) reported milk yield decline by $0.2 \mathrm{~kg}$ per unit increase in THI when THI exceeded 72. The extent of milk yield decline observed in heat-stressed cows is dependent on several factors that interact with high air temperature. Buffalo exposure to high temperatures also reduces milk production because it affects the animal physiological functions, such as pulse, respiration rate, and rectal temperature (Seerapu et al., 2015), however, less attention has been given to this species (Nardone et al., 2010). The increase in milk yield increases sensitivity of cattle to thermal stress and reduces the threshold temperature at which milk losses occur (Berman, 2005). According to the studies by Berman, (2005) and Nardone et al., (2010) when high milk producing cattle were kept in hot climatic zones, metabolic heat production was intensified that resulted in an increased respiratory rate, consequently decreased the milk production. Molee et al., (2011) found that Holstein crossed with local breeds in the tropics and subtropics perform better than the pure bred Holstein and were also resistant to heat stress. Purwanto et al., (1990) reported that when non-lactating, lower milk yielding $(18.5 \mathrm{~kg} / \mathrm{d})$ or high yielding $(31.6 \mathrm{~kg} / \mathrm{d})$ cows were compared, low and high yielding cows produced 27 and 48 per cent more heat than non-lactating cows despite of having lower body weights (752, 624 , and $597 \mathrm{~kg}$ for non-lactating, low, and high producers, respectively). The stage of lactation is also an important factor affecting dairy cow's responses to heat. In general, dairy animals are more prone to heat during mid-lactation compared to early or late lactation stage. Upadhyay et al., (2007) observed the extent of decline in milk yield were less at mid lactation stage than either late or early stage and decline in yield varied from 10 -30 per cent in first lactation and 5-20 per cent in second or third lactation in Murrah buffaloes. Das et al., (2016) concluded that the heat stress during the dry period reduced mammary cell proliferation which decreased the milk yield in following lactation. The decline in milk production due to heat stress was 14 and 35 per cent in early and midlactation, respectively. They further added that average milk production in HolsteinFriesian during early lactation period (first 60 days of lactation) was significantly $(\mathrm{p}<0.05)$ higher in spring $(42.74 \pm 4.98$ litres) than in summer (39.60 \pm 5.09 litres) seasons.

In general, small ruminants especially ewes are more sensitive to the combined temperature and relative humidity affect (the temperature humidity index) than actual temperature or relative humidity. However, 
the index values that trigger heat stress on ewes varies by breed type (Finocchiaro et al., 2005). The values of THI, above which ewes start to suffer from heat stress, seem to be quite different among breeds of sheep. Solar radiation seems to have a lesser effect on milk yield, but a greater effect on milk composition of Comisana ewes (Sevi et al., 2001). High air temperatures even affect goats, reducing milk yield and the content of milk components. In particular, if lactating goats are deprived of water during the hot season, they activate a water loss reduction mechanism for reducing water loss in urine, milk and by evaporation, to maintain milk production for a longer time (Olsson and Dahlborn, 1989).

\section{Impact on animal reproduction}

Heat stress due to high ambient temperature accompanied with excess humidity during summer months causes infertility in most of the farm species and have adverse effect on reproductive performance of farm animals. During hot dry (March- June) and hot humid (July- September) seasons, the THI values exceeds 80 in most parts of India. Most of the buffaloes exhibit sexual activity during cooler parts of the year (October- Feb), when the THI generally remains < 72 (Upadhyay et al., 2009). A temperature rise of more than $2^{\circ} \mathrm{C}$ in unabated buffaloes may cause negative impacts due to low or desynchronized endocrine activities particularly pinealhypothalamo-hypophyseal-gonadal axis altering respective hormone functions (Upadhyay et al., 2009), whereas in case of cattle, the effects of heat stress on fertility appear to carry into the autumn (October and November) even though the cows are no longer exposed to heat stress (Drew, 1999). Low temperature and THI during nights in summer (April and May) provide an opportunity to buffaloes to dissipate heat during night hours compared to day hours. This may be the reason that buffaloes experienced less stress during hot dry season compared with hot humid season (Upadhyay et al., 2009). It was reported that the climate change also influenced calving of buffaloes and maximum number of calvings occurred in winter season followed by rainy and summer seasons (Kamble et al., 2014). They further reported that the peak milk yield was highest among buffaloes calved during winter season as compared to rainy and summer season, and buffaloes calved during winter had longest lactation length.

Reproductive efficiency of both livestock sexes may be affected by heat stress. In cows and pigs, it affects oocyte growth and quality (Ronchi et al., 2001 and Barati et al., 2008), impairment of embryo development, and pregnancy rate (Wolfenson et al., 2000, Hansen, 2007 and Nardone et al., 2010). Amundson et al., (2006) reported decrease in pregnancy rates of Bos taurus cattle of 3.2 per cent for each unit increase in average THI 70, and a decrease of 3.5 per cent for each increase in average temperature above $23.4^{\circ}$ C. They further reported that the environmental variable i.e. minimum temperature of the day had the greatest influence on the percent of cows getting pregnant were not adapted to these conditions. Heat shock leads to embryonic death, at least in part, because protein synthesis is reduced (Edwards and Hanseen, 1997) and concentration of free radicals increases. In addition to effects on embryonic mortality heat stress reduces the duration and intensity of sexual behavior and estrus incidences (Naqvi et al., 2004).

Diurnal pattern of estrus behaviour has been observed in majority of Murrah buffaloes. During heat stress, motor activity and other manifestations of estrus are reduced and the incidence of anestrus and silent ovulation is increased (Nebel et al., 1997). Collier et al., (1982) reported that dairy cows experiencing 
heat stress during late gestation had calves with lower birth weights and produced less milk than cows not exposed to heat stress. Reproductive processes in male animal are also very sensitive to disruption by hyperthermia with the most pronounced consequences being reduced quantity and quality of sperm production and decreased fertility. Scrotal circumference, testicular consistency, tone, size and weight are decrease in hot summer in the sub tropics than those of the same breeds of buffalo reared under temperate environmental conditions. It is reported that ejaculate volume, concentration of spermatozoa and sperm motility in bulls are lower in summer than in winter season (Samal, 2013).

\section{Impact on fodder and water availability}

Higher temperatures increase lignin formation in plant tissues and thereby reduce the digestibility and rates of degradation of fodder and crop residues in the ruminants. Climate change is expected to change the species composition (and hence biodiversity and genetic resources) of grasslands as well as affect the digestibility and nutritional quality of forage (Thornton et al., 2009). A decrease in forage quality can increase methane emissions per unit of gross energy consumed (Benchaar et al., 2001). Therefore, if forage quality declines, it may need to be offset by decreasing forage intake and replacing it with grain to prevent elevated methane emissions by livestock (Polley et al., 2013). Droughts and extreme rainfall variability can trigger periods of severe feed scarcity, especially in dry land areas, with devastating effects on livestock populations. Water availability issues will influence the livestock sector, which uses water for animal drinking, feed crops, and product processes (Thornton et al., 2009). The livestock sector accounts for about 8 per cent of global human water use and an increase in temperature may increase animal water consumption by a factor of two to three and to address this issue, there is a need to produce crops and raise animals in livestock systems that demand less water or in locations with water abundance (Nardone et al., 2010).

\section{Impact on feed intake}

Livestock have several nutrient requirements including energy, protein, minerals, and vitamins, which are dependent on the region and type of animal. Failure to meet the dietary needs of cattle during heat stress affects metabolic and digestive functions (Mader, 2003). Sodium and potassium deficiencies under heat stress may induce metabolic alkalosis in dairy cattle, increasing respiration rates. Heat stress in such high producing lactating dairy cows results in dramatic reductions in roughage intake and rumination. The reduction in appetite under heat stress is a result of elevated body temperature and may be related to gut fill. Decreased roughage intake contributes to decreased VFA production and may lead to alterations in the ratio of acetate and propionate. In addition, rumen $\mathrm{pH}$ is depressed during heat stress (Collier et al., 1982).

\section{Impact on livestock health}

The impacts of changes in ecosystems on infectious diseases depend on the ecosystems affected, the type of land-use change, disease characteristics, and the susceptibility of the populations at risk. Global climate change alters ecological construction which causes both the geographical and phonological shifts (Slenning, 2010). These shifts affect the efficiency and transmission pattern of the pathogen and increase their spectrum in the hosts (Brooks and Hoberg, 2007). The increased spectrum of pathogens increases the disease susceptibility of the animal and thus, supports the pathogenicity of the causative agent. The livestock systems are susceptible 
to changes in severity and distribution of livestock diseases and parasites as potential consequences. Incidence of external parasite $(43.3 \%)$ was first ranked as the problem in the warm temperate (Dhakal et al., 2013).

\section{Effects on vectors}

The epidemiology of many diseases are based on transmission through vectors such as ticks, lice, mites, mosquitoes and flies, the developmental stages of which are often heavily dependent on temperature and humidity. Changes in rainfall and temperature regimes may affect both the distribution and the abundance of disease causing vectors, as can changes in the frequency of extreme events (Thornton et al., 2009). The feeding frequency of arthropod vectors may also increase with rises in temperature. As many vectors must feed twice on suitable hosts before transmission is possible (to acquire and then to transmit the infection), warmer temperatures may increase the likelihood of successful disease transmission. The hothumid weather conditions were found to aggravate the infestation of cattle ticks like, Boophilu smicroplus, Haemaphysalis bispinosa and Hyalommaanatolicum (Basu and Bandhyopadhyay, 2004 and Kumar et al., 2004).

\section{Effects on pathogens}

Temperature increases could accelerate the growth of pathogens and/or parasites that live part of their life cycle outside of their host, which negatively affects livestock (Patz et al., 2000 and Harvell et al., 2002). Higher temperatures resulting from climate change may increase the rate of development of certain pathogens or parasites that have one or more life cycle stages outside their animal host. This may shorten generation times and, possibly, increase the total number of generations per year, leading to higher pathogen/parasite population sizes. Conversely, some pathogens are sensitive to high temperatures and their survival may decrease with climate warming. Pathogens and parasites that are sensitive to moist or dry conditions may be affected by changes to precipitation, soil moisture and the frequency of floods. Changes to winds could affect the spread of certain pathogens and vectors. Some pathogens/parasites and many vectors experience significant mortality during cold winter conditions; warmer winters may increase the likelihood of successful overwintering (Harvell et al., 2002).

\section{Effects on hosts}

Climate change may bring about substantial shifts in disease distribution, and outbreaks of severe disease could occur in previously unexposed animal populations (Thornton et $a l ., 2009)$. Endemic stability occurs when the disease is less severe in younger than older individuals, when the infection is common or endemic and when there is lifelong immunity after infection. Certain tick-borne diseases of livestock in Africa, such as anaplasmosis, babesiosis and cowdriosis, show a degree of endemic stability (Eisler et al., 2003).

\section{Impact on biodiversity}

Biodiversity refers to a variety of genes, organisms, and ecosystems found within a specific environment and contribute to human well-being (Swingland, 2001). Populations that are decreasing in genetic biodiversity are at risk, and one of the direct drivers of this biodiversity loss is climate change. Climate change may eliminate 15 to 37 per cent of all species in the world (Thomas et al., 2004). The Intergovernmental Panel on Climate Change Fifth Assessment Report states that an increase of 2 to $3^{\circ} \mathrm{C}$ above pre-industrial levels may result in 20 to 30 per cent of biodiversity loss of plants and animals (IPCC, 
2013). Out of the 3831 breeds of ass, water buffalo, cattle, goat, horse, pig, and sheep recorded in the twentieth century, at least 618 had become extinct by the century's end, and 475 of the remainder were rare. Cattle had the highest number of extinct breeds $(\mathrm{N}=209)$ of all species evaluated. The livestock species that had the highest percentages of risk of breed elimination were chicken $(33 \%$ of breeds), pigs ( $18 \%$ of breeds), and cattle (16\% of breeds) The FAO (2006) report on animal genetic resources indicates that 20 per cent of reported breeds are now classified as at risk, and that almost one breed per month is becoming extinct. For developing regions, the proportion of mammalian species at risk is lower (7-10\%), but 60-70 per cent of mammals are classified as being of unknown risk status.

In conclusion, climate change has influenced animals adversely. In near future, many livestock breeds and plant species will be highly affected by climate change and these breeds and species cannot be replaced naturally; therefore, future research on the inherent genetic capabilities of different breeds and identification of those that can better adapt to climate conditions is vital.

\section{References}

Amundson, J.L., Mader, T.L., Rasby, R.J. and $\mathrm{Hu}$, Q.S. 2006. Environmental effects on pregnancy rate in beef cattle. J. of Anim. Sci., 84: 3415-3420.

Bellarby, J., Tirado, R., Leip, A., Weiss, F., Lesschen, J.P., and Smith, P., 2013. Livestock greenhouse gas emissions and mitigation potential in Europe. Glob. Change Biol. 19, 3-18.

FAO, 2006. Steinfeld, H., Gerber, P., Wassenaar, T., Castel, V., Rosales, M., de Haan, C. (eds.) Livestock's long shadow. Environmental issues and options. http://fao.org/docrep.
IPCC (Intergovernmental Panel on Climate Change), 2007. Climate Change: Synthesis Report; Summary for Policymakers. Retrieved from: http://www.ipcc.ch/pdf/assessmentreport/ar4/syr/ar4_syr_spm.pdf.

IPCC (Intergovermental Panel on Climate Change), 2013. Climate change 2013: The physical science basis. In: Stocker, T.F., Qin, D., Plattner, G.-K., Tignor, M., Allen, S.K., Boschung, J., Nauels, A., Xia, Y., Bex, V. and Midgley, P.M. (Eds.), Contribution of Working Group I to the Fifth Assessment Report of the Intergovernmental Panel on Climate Change. Cambridge University Press, Cambridge, United Kingdom and New York, NY, USA, p. 1535.

Barati, F., Agung, B., Wongsrikeao, P., Taniguchi, M., Nagai, T. and Otoi, T., 2008. Meiotic competence and DNA damage of porcine oocytes exposed to an elevated temperature. Theriogenology 69, 767-772.

Basu, A.K., and Bandhyopadhyay, P.K. 2004. The effect of season on the incidence of ticks. Bull. Anim. Health Prod. Afr., 52(1): 39-42.

Benchaar, C., Pomar, C., and Chiquette, J. 2001. Evaluation of dietary strategies to reduce methane production in ruminants: a modeling approach. Can. J. Anim. Sci. 81, 563-574.

Berman, A. 2005. Estimates of heat stress relief needs for Holstein dairy cows. J. Anim. Sci., 83(6): 1377-1384.

Brooks, D.R., and Hoberg, E.P. 2007. How will global climate change affect parasite host assemblages. Trends Parasitol. 23: 571-574.

Collier, R.J., Doelger, S.G., Head, H.H., Thatcher, W.W. and Wilcox, C.J. 1982. Effects of heat stress during pregnancy on maternal hormone concentrations, calf birth weight and postpartum milk yield of Holstein cows. J. Anim. Sci. 
54: 309-319.

Das, R., Sailo, L., Verma, N., Bharti, P., and Saikia, J. 2016. Impact of heat stress on health and performance of dairy animals: A review. Vet. World 9(3): 260-268.

Dhakal, C.K., Regmi, P.P., Dhakal, I.P., Khanal, B., Bhatta, U.K., Barsila, S.R., and Acharya, B. 2013. Perception, Impact and Adaptation to Climate Change: An Analysis of Livestock System in Nepal. J. Anim. Sci. Adv., 3(9): 462-471.

Drew, B. 1999. Practical nutrition and management of heifers and high yielding dairy cows for optimal fertility. Cattle Pract. 7: 243-248.

Edwards, J.L., and Hansen, P.J. 1997. Differential responses of bovine oocytes and pre-implantation embryos to heat shock. Mol. Reprod. Dev. 46: 138-145.

Eigenberg, R.A., Brown, B.T.M., and Nienaber, J.A. 2007. Development of a livestock weather safety monitor for feedlot cattle. Appl. Eng. Agric. 23(5): 657-660.

Eisler, M.C., Torr, S.J., Coleman, P.G., Machila, N., and Morton, J.F. 2003. Integrated control of vector-borne diseases of livestock - pyrethroids: panacea or poison? Trends Parasitol. 19: 341-345.

Finocchiaro, R., Van Kaam, J., Portolano, B., and Misztal, I. 2005. Effect of heat stress on production of dairy sheep. J. Dairy Sci. 88: 1855-1864.

Hansen, P.J., 2007. Exploitation of genetic and physiological determinants of embryonic resistance to elevated temperature to improve embryonic survival in dairy cattle during heat stress. Theriogenology, 68 (4): $242-$ 249.

Harvell, C.D., Mitchell, C.E., Ward, J.R., Altizer, S., Dobson, A.P., Ostfeld, R.S., and Samuel, M.D., 2002. Climate warming and disease risks for terrestrial and marine biota. Science 296: 21582162.

Kadzere, C.T., Murphy, M.R., Silanikove, N., and Maltz, E., 2002. Heat stress in lactating dairy cows: a review. Liv. Prod. Sci. 77: 59-91.

Kamble, S.S., Chauhan, D.S., and Bhise, B.R. 2014. Impact of climatic parameters on milk production in Murrah buffaloes. $\mathrm{J}$. Crop Weed. 10: 71-76.

Koubkova, M., Knizkova, I., Kunc, P., Hartlova, H., Flusser, J., and Dolezal, O. 2002. Influence of high environmental temperatures and evaporative cooling on some physiological, hematological and biochemical parameters in high-yielding dairy cows. Czech. J. Anim. Sci. 47: 309-318.

Kumar, S., Prasad, K.D., and Deb, A.R. 2004. Seasonal prevalence of different ectoparasites infecting cattle and buffaloes. BAU. J. Res. 16(1): 159-163.

Mader, T.L., 2003. Environmental stress in confined beef cattle. J. Anim. Sci. 81: 110-119.

Molee, A., Bundasak, B., Petladda, K., and Plern, M. 2011. Suitable percentage of Holstein in crossbred dairy cattle in climate change situation. J. Anim. Vet. Advn. 10(7): 828-831.

Nardone, A., Ronchi, B., Lacetera, N., Ranieri, M.S., and Bernabucci, U. 2010. Effects of climate changes on animal production and sustainability of livestock systems. Livest. Sci. 130: 5769.

Naqvi, S.M.K., Maurya, V.P., Gulyani, R., Joshi, A., and Mittal, J.P. 2004. Effect of thermal stress on superovulatory response and embryo production in Bharat Merino ewes. Small Rum. Res. 55: 57-63.

Nebel, R.L., Jobst, S.M., Dransfield, M.B.G., Pandolfi, S.M., and Bailey, T.L. 1997. 
Use of radio frequency data communication system, Heat Watch ${ }^{\circledR}$, to describe behavioral estrus in dairy cattle. J. Dairy Sci. 80(Suppl. 1.): 179.

Olsson, K., and Dahlborn, K. 1989. Fluid balance during heat stress in lactating goats. Q. J. Exp. Physiol. 74: 645-659.

Patz, J.A., Graczyk, T.K., Geller, N., and Vittor, A.Y. 2000. Effects of environmental change on emerging parasitic diseases. Int. J. Parasitol. 30: 1395-1405.

Polley, H.W., Briske, D.D., Morgan, J.A., Wolter, K., Bailey, D.W., and Brown, J.R., 2013. Climate change and North American rangelands: trends, projections, and implications. Rangeland Ecol. Manage. 66: 493-511.

Purwanto, B.P., Abo, Y., Sakamoto, R., Furumoto, F., and Yamamoto, S. 1990. Diurnal patterns of heat production and heart rate underthermo neutral conditions in Holstein Friesian cows differing in milk production. J. Agric Sci., (Camb.). 114: 139-142.

Ravagnolo, O., and Misztal, I. 2000. Genetic component of heat stress in dairy cattle, parameter estimation. J. Dairy Sci. 83: 2126-2130.

Reynolds, C., Crompton, L., and Mills, J. 2010. Livestock and climate change impacts in the developing world. Outlook Agric. 39: 245-248.

Ronchi, B., Stradaioli, G., VeriniSupplizi, A., Bernabucci, U., Lacetera, N., Accorsi, P.A., Nardone, A., and Seren, E. 2001. Influence of heat stress and feed restriction on plasma progesterone, estradiol-17b LH, FSH, prolactin and cortisol in Holstein heifers. Livest. Prod. Sci. 68: 231-241.

Samal, L. 2013. Heat Stress in Dairy Cows Reproductive Problems and Control Measures. Int. J. Livest. Res. 3(3): 1423.

Seerapu, S.R., Kancharana, A.R., Chappidi,
V.S., and Bandi, E.R. 2015. Effect of microclimate alteration on milk production and composition in Murrah buffaloes. Vet. World 8: 1444-1452.

Sevi, A., Annicchiarico, G., Albenzio, M., Taibi, L., Muscio, A., and Dell'Aquila, S. 2001. Effects of solar radiation and feeding time on behavior, immune response and production of lactating ewes under high ambient temperature. J. Dairy Sci. 84: 629-640.

Slenning, B.D. 2010. Global climate change and implications for disease emergence. Vet. Pathol. 47(1): 28-33.

St-Pierre, N.R., Cobanov, B., and Schnitkey, G. 2003. Economic Losses from Heat Stress by US Livestock Industries. J. Dairy Sci. 86: 52-57.

Swingland, I.A. 2001. Biodiversity, definition of. Encyclopedia of Biodiversity 1: 377-391.

Thomas, C.D., Cameron, A., Green, R.E., Bakkenes, M., Beaumont, L.J., Collingham, Y.C., Erasmus, B.F.N., de Siqueira, M.F., Grainger, A., Hannah, L., Hughes, L., Huntley, B., van Jaarsveld, A.S., Midgley, G.F., Miles, L., Ortega-Huerta, M.A., Peterson, A.T., Phillips, O.L., and Williams, S.E. 2004. Extinction risk from climate change. Nature 427: 145-148.

Thornton, P.K., and Gerber, P.J. 2010. Climate change and the growth of the livestock sector in developing countries. Mitig. Adapt. Strategies Global Change 15, 169-184.

Thornton, P., van de Steeg., J., Notenbaert, M.H., and Herrero, M. 2009. The impacts of climate change on livestock and livestock systems in developing countries: A review of what we know and what we need to know. Agri. Systems 101: 113-127.

Upadhaya, R. C., Singh S.V., Kumar, A., Gupta, S. K., and Ashutosh. 2007. Impact of climate change on Milk 
production of Murrah buffaloes. Italian J. Anim. Sci., 6 (Suppl. 2): 1329-1332.

Upadhyay, R.C., Singh, S.V. and Ashutosh. 2008. Impact of climate change on livestock. Indian Dairyman 60(3): 98102.

Upadhaya, R. C., Ashutosh, Kumar, A., Gupta, S.K., Gupta, S.V., Singh, S.V., and Rani, N. 2009. Inventory of methane emission from livestock in
India. In, Global climate change and Indian agriculture. Case studies from the ICAR Network project. P.K. Aggarwal (Ed), ICAR, New Delhi. PP 117-122.

Wolfenson, D., Roth, Z., and Meidan, R., 2000. Impaired reproduction in heatstressed cattle: basic and applied aspects. Anim. Rep. Sci. 60 (1-3): 535547.

\section{How to cite this article:}

Ramandeep Kaur, Parteek Singh Dhaliwal and Dhindsa, S.S. 2019. Impact of Climate Change on Livestock- A Review. Int.J.Curr.Microbiol.App.Sci. 8(05): 1710-1719. doi: https://doi.org/10.20546/ijcmas.2019.805.198 